\title{
Notes
}

\section{Stereotyping and Difference:}

\section{Planned Parenthood v. Casey and the Future of Sex Discrimination Law}

\section{David H. Gans}

In Planned Parenthood v. Casey, the Supreme Court reaffirmed the holding of Roe $v$. Wade ${ }^{2}$ that the Constitution protects a woman's right to choose abortion before fetal viability. But the Casey joint opinion ${ }^{3}$ based its holding not only on the right to privacy recognized in Roe, but also on principles of sex equality. Many scholars have recognized the significant equality themes that run through the Casey joint opinion."

Casey's recognition of the sex discrimination inherent in restrictive abortion laws highlights the paradox of modern sex discrimination law under the Fourteenth Amendment. Although the Court has invalidated statutes under the Equal Protection Clause based on the sort of role typing condemned by the Casey joint opinion, the Equal Protection Clause does not provide any protection against restrictive abortion laws. ${ }^{6}$ Indeed, abortion laws fall outside equal protection analysis even while the Court claims that the central purpose

1. 112 S. Ct. 2791 (1992).

2. 410 U.S. 113 (1973).

3. The lead opinion in Casey was a joint opinion coauthored by Justices $O^{\prime}$ Connor. Kennedy, and Souter. Justices Stevens and Blackmun joined the portions of the joint opinion reaffirming Roe and invalidating Pennsylvania's husband-notification statute.

4. See, e.g., Ruth Bader Ginsburg. Speaking in a Judicial Voice, 67 N.Y.U. L. REV. 1185, 1199-1200 (1992).

5. See, e.g., Mississippi Univ. for Women v. Hogan. 458 U.S. 718 (1982).

6. See Cass R. Sunstein, The Partial Constitution 284 (1993). 
of its sex discrimination jurisprudence under the Equal Protection Clause is to prohibit states from enacting laws based on stereotypical notions of women's proper roles. This Note explores this contradiction, examining how the Supreme Court reasons about stereotyping in the area of reproductive differences, and attempts to use the opinion in Casey to suggest a fuller concept of stereotyping and equal protection analysis.

Part I of this Note examines the centrality of stereotyping analysis to modern sex discrimination law under the Equal Protection Clause, noting especially the Court's understanding of stereotypes and the harms that flow from them. Part II looks at the doctrinal structure of stereotyping analysis, focusing on how the Court's narrow definition of sex-based classifications mediates the stereotyping inquiry. This Part then looks at equal protection cases involving women's reproductive capacity. In some cases, the Court, without conducting its stereotyping analysis, upholds statutes that discriminate against pregnant women. In other cases, the Court adopts a narrow understanding of stereotyping, limited to a failure to recognize similarities between men and women. This narrow definition does not cover stereotypical judgments about the proper roles of women when they are based on biological differences between the sexes.

Arguing from the historical treatment of women's reproductive differences, Part III suggests that harmful stereotyping has occurred and still occurs where men and women are not similarly situated. This Part examines the Court's decision in Casey and the different understanding of stereotyping we see in the joint opinion. It concludes by formulating a model of equal protection analysis based on the Casey joint opinion's equality analysis. Part IV applies the model suggested above to pregnancy discrimination and restrictive abortion laws. Finally, it suggests how we might rethink the comparison principle at the heart of equal protection law to produce a fuller understanding of equality in the context of sex differences.

\section{Stereotyping as the Central Principle of SEX DISCRIMINATION LAW}

Stereotyping is the central evil that the Court's equal protection doctrine seeks to prevent. Indeed, the Court has described the harm of sex-based classification in terms of stereotypes about the proper roles of women. As Justice Brennan explained in Orr v. Orr, "Legislative classifications which distribute benefits and burdens on the basis of gender carry the inherent risk of reinforcing stereotypes about the 'proper place' of women and their need for special protection." In evaluating constitutional challenges to laws that

7. Orr v. Orr, 440 U.S. 268, 283 (1979); see also J.E.B. v. Alabama ex rel. T.B., 114 S. Ct. 1419 , 1424-25 (1994) (recognizing that heightened scrutiny of gender-based classifications is necessary because 
discriminate based on sex, the Supreme Court has consistently held that state laws and practices reflecting stereotypical assumptions about women's proper roles are invalid under the Equal Protection Clause. ${ }^{8}$

Before examining the Court's decisions in this area, it will be useful to develop an understanding of the psychological concept of stereotyping. Stereotyping is a part of the normal process of categorization. ${ }^{9}$ In a world too complex to know first hand, people need a way to simplify and organize. Stereotypes serve this function. As Walter Lippmann observed, stereotypes are the "pictures in our heads" that allow us to make sense of a world "with so much subtlety, so much variety, so many permutations and combinations."10

In categorizing the world, stereotypes describe the characteristics and personality traits that belong to individuals in a social group. For example, sex stereotypes describe men as strong, aggressive, and independent, women as passive, nurturing, and dependent. "These claims about men's and women's natures, like stereotypes about other groups, "often are overgeneralizations and are either inaccurate or do not apply to the individual" in question. ${ }^{12}$

Stereotypes also identify the expected patterns of behavior for a particular social group. Sex-role stereotypes specify the behaviors that are appropriate for men and for women. ${ }^{13}$ These stereotypes define the proper roles of men and women not by reference to individuals' personality traits, but by the type of conduct desirable for each sex. While sex stereotyping makes an empirical generalization about the sexes, sex-role stereotyping is based on normative assumptions about the proper roles of men and women. ${ }^{\text {is }}$

The Supreme Court's sex discrimination jurisprudence recognizes both sorts of stereotyping identified in the psychological literature: empirical generalizations and normative assumptions about the proper roles of women. ${ }^{15}$

of "real danger that government policies that professedly are based on reasonable considerations in fact may be reflective of 'archaic and overbroad' generalizations about gender or based on 'outdated misconceptions concerning the role of females in the home rather than in the marketplace and world of ideas." (citations omitted)).

8. See J.E.B., 114 S. Ct. at 1422; Califano v. Westcott. 443 U.S. 76.89 (1979): Orr, 440 U.S. at 279-80; Califano v. Goldfarb, 430 U.S. 199, 210-11 (1977) (plurality opinion).

9. See Shelley E. Taylor, A Categorization Approach to Stereoryping, in CooNmVE PROCESSES IN STEREOTYPING AND INTERGROUP BEHAvIOR 83. 84-85 (David L. Hamilton ed.. 1981) (hereinafter COGNITTVE PROCESSES IN STEREOTYPING].

10. Walter LipPMANn, PUblic Opinion 3. 11 (1922); see also Miadeline E. Heilman. Sex Btas in Work Settings, in 5 RESEARCH IN ORGANIZATIONAL BehAVIOR 269. 271 (L.L. Cummings \& Barty M. Staw eds., 1983) (describing stereotypes as "a set of attributes ascribed to a group and imputed to its individual members simply because they belong to that group").

11. See Heilman, supra note 10, at 272 .

12. Id at 271 (emphasis omitted).

13. For a discussion of the difference between sex stereotypes and sex-role stereotypes, see Drana $N$. Ruble \& Thomas L. Ruble, Sex Stereotypes, in in the Eye OF THE BeHOLDER: CONTEMPORARY Issues IN STEREOTYPING 188, 194 (Arthur G. Miller od., 1982) (hereinafter IN THE EYE OF THE BEHOLDER].

14. See Richard D. Ashmore \& Frances K. Del Boca, Conceptual Approaches to Stereonpes and Stereotyping, in COGNITIVE PROCESSES IN STEREOTYPING, supra note 9. at 1. 21 ; James R. Terborg. Women in Management, $62 \mathrm{~J}$. APPLIED PSYCHOL. 647, 650 (1977).

15. Reva Siegel, Reasoning from the Body: A Historical Perspective on Abortion Regulatton and 
For example, the Court condemned a policy based on normative assumptions about the proper roles of women in Mississippi University for Women $v$. Hogan. ${ }^{16}$ In Hogan, the Court invalidated a state nursing school's policy of excluding men from admission because the policy "reflect[ed] archaic and stereotypic notions" of the "proper roles of men and women." rejected the argument that the exclusion of men was necessary to compensate for discriminatory barriers faced by women, finding instead that the university's admission policy "perpetuate[d] the stereotyped view of nursing as an exclusively women's job."18

The Hogan Court noted that the nursing school's assumptions about the proper roles of women harmed the women who conformed to those assumptions by depressing the wages paid to nurses. ${ }^{19}$ The Court also recognized the broader harms to women caused by stereotyping. It recognized that government policies based on stereotypes about women's proper roles are unjust-not only to women who do not fit the particular stereotype, but to all women-because they convert stereotypical assumptions about women's proper roles into reality, forcing women into constricted social roles. As Justice O'Connor explained, by excluding males from admission, the nursing school policy made the "assumption that nursing is a field for women a self-fulfilling prophecy."20

The link between empirical generalizations and normative assumptions about the proper roles of women is critical to understanding why the Court has found laws based on empirical generalizations about women to violate the Equal Protection Clause. Empirical generalizations occur frequently in legislation; indeed, as John Hart Ely has noted, such generalizations are an essential part of legislation. ${ }^{21}$ The Equal Protection Clause, in most cases, does not prohibit the use of such generalizations in creating laws. ${ }^{22}$ In the area of sex stereotyping, however, statutes based on inaccurate generalizations about the roles and abilities of men and women are unconstitutional because these generalizations perpetuate offensive normative assumptions about women's proper roles. ${ }^{23}$

Questions of Equal Protection, 44 STAN. L. REv. 261, 355-56 (1992).

16. 458 U.S. 718 (1982).

17. Id. at 725,726 .

18. Id. at 729 .

19. Id. at $729-30 \&$ n. 15 .

20. Id. at 730 .

21. See John Hart Ely, DEMOCRACY AND DISTRUST 156 (1980); see also Cleveland Bd. of Educ. v. LaFleur, 414 U.S. 632, 660 (1974) (Rehnquist, J., dissenting) (noting that requirement that legislature provide individualized determinations in drawing statutory classifications is "nothing less than an attack upon the very notion of lawmaking itself').

22. See Williamson v. Lee Optical Co., 348 U.S. 483, 489 (1955).

23. This is true even where a generalization reflects a substantial measure of truth. As the Court recently noted, "gender classifications that rest on impermissible stereotypes violate the Equal Protection Clause, even when some statistical support can be conjured up for the generalization." J.E.B. v. Alabama ex rel. T.B., 114 S. Ct. 1419, 1427 n.11 (1994). 
For example, in Weinberger $v$. Wiesenfeld, ${ }^{24}$ the Cour invalidated a statute that provided to a widow and her children Social Security benefits based on the earnings of a deceased husband, but denied to the widower benefits based on the earnings of his deceased wife. The provision was invalid because it rested on the "overbroad generalization" that women, but not men, are dependent on the wages earned by their spouses. ${ }^{25}$ Yet, as the facts of the Weinberger case show, women's wage-earning work can be absolutely vital to a family's efforts to live a decent life. By labeling wives as dependents and husbands as breadwinners, Congress perpetuated the stereotype of female dependency, reinforcing the notion that men, not women, should be the primary wage earners for a family.

Weinberger demonstrates the necessary connection between assumptions about what women are and assumptions about what women should be. Judgments about the traits possessed by women reinforce notions about what the proper roles of women should be, making stereotypical judgments about women's roles and abilities into self-fulfilling prophecies. Legislation that rests on such stereotypical notions about the proper roles of women is unconstitutional under the Equal Protection Clause because it "reinforce[s] . . . stereotypes about the group's competence or predispositions that have been used to prevent them from voting, participating on juries, pursuing their chosen professions, or otherwise contributing to civic life." ${ }^{26}$ At the core of the prohibition on stereotyping, then, is the notion that state practices and policies based on stereotypes block women's choice of social roles, preventing them from fully taking part in American society. Such policies are inconsistent with the notion of equal citizenship at the core of the Equal Protection Clause. This link between overbroad generalizations and women's roles explains why the Court's stereotyping analysis is not simply an across-the-board attack on the "inevitable stuff of legislation." 28

The Supreme Court's sex discrimination jurisprudence, however, analyzes inaccurate and overbroad generalizations in terms of similarities between the sexes. The Court only invalidates legislation based on impermissible stereotyping when the stereotyping involves a failure to recognize similarities between men and women. For example, in Weinberger, by failing to recognize that both men and women could be the primary wage earners for a household, the statute provided "dissimilar treatment for men and women who are ...

24. 420 U.S. 636 (1975).

25. Id. at 643 .

26. J.E.B., 114 S. Ct. at 1428 n.14; see also City of Clebume v. Cleburne Living Cir., Inc., 473 U.S. 432, 440-41 (1985) ("“[W]hat differentiates sex from... nonsuspeet statuses... is that the sex characteristic frequently bears no relation to ability to perform or contribute to sociely.'” (quoung Frontiero v. Richardson, 411 U.S. 677, 686 (1973) (plurality opinion))).

27. Kenneth L. Karst, The Supreme Coun, 1976 Term-Foreword: Equal Ctuzenship Under the Fourteenth Amendment, 91 HARV. L. REV. 1, 23-26, 55 (1977).

28. ELY, supra note 21 , at 156. 
similarly situated" in violation of the Equal Protection Clause. ${ }^{29}$ Under the Court's current doctrine, the "harm of stereotyping," Catharine MacKinnon has noted, is the assumption that "all women are the same and/or like some mythic feminine standard, and inherently and irredeemably different from men."30

This focus on sameness versus difference underlies the problems in the Supreme Court's understanding of stereotyping. Stereotyping is not simply reducible to a failure to recognize similarities between the sexes. Psychologists have defined stereotypes as a set of beliefs about a group's personal attributes-both personality traits and norms of expected behavior, ${ }^{31}$ they have not focused on issues of sameness and difference. Moreover, psychologists have suggested that aspects of an "individual's physiological or biological identity" are often the stimuli for stereotypical judgments. ${ }^{32}$ This is especially true in the area of sex and sex-role stereotyping, where stereotypes are generally based on "assumed or perceived sex differences.",33 Consequently, any stereotyping inquiry should not focus solely on the biological similarities or differences between men and women. Rather, courts should scrutinize statutes to see if they are based on generalizations about the roles and abilities of women and normative expectations about appropriate behavior for women.

The Supreme Court's sameness/difference framework allows the state to perpetuate outmoded notions about women's proper roles where men and women are different. Women's differences from men do not dictate their social roles. As Ann Freedman has explained, it is "social arrangements and not biology that give[] [sex differences] meaning.... [P]articular human characteristics have no inherent social significance, and no social arrangements concerning sex differences are 'natural' rather than culturally determined."34 Rather, society constructs women's roles precisely in terms of their differences from men. ${ }^{35}$ The Court has never recognized this point because sex

29. Weinberger, 420 U.S. at 653 (quoting Reed v. Reed, 404 U.S. 71, 77 (1971)); see also Vicki Schultz, Telling Stories About Women and Work: Judicial Interpretations of Sex Segregation in the Workplace in Title VII Cases Raising the Lack of Interest Argument, 103 HARV. L. REV. 1749, 1806 (1990) (equating stereotyping analysis with "familiar principle that likes are to be treated alike").

30. Catharine A. MacKinnon, Reflections on Sex Equality Under Law, 100 YALE L.J. 1281, 1292 (1991); see also Sylvia A. Law, Rethinking Sex and the Constitution, 132 U. PA. L. REv. 955, 1004 (1984) ("The prevailing sex equality standard determines whether the sex-based classification at issue actually is responsive to real differences between men and women and rejects classifications when there are no such differences.").

31. See Ashmore \& Del Boca, supra note 14, at 21; supra notes 11-14 and accompanying text.

32. Arthur G. Miller, Historical and Contemporary Perspectives on Stereotyping, in IN THE EYE OF THE BEHOLDER, supra note 13, at 1, 29.

33. See Ashmore \& Del Boca, supra note 14, at 20.

34. Ann E. Freedman, Sex Equality, Sex Differences, and the Supreme Court, 92 YALE L.J. 913, 945 (1983).

35. See MacKinnon, supra note 30, at 1290 ("Society defines women as such according to differences from men: hence the sex difference, as gender is customarily termed."). 
discrimination law is structured to avoid looking at stereotyping where there are categorical sex differences between men and women. ${ }^{36}$

\section{STEREOTYPING AND tHE STRUCtURE OF SEX DisCRIMINATION LAW}

\section{A. The Structure of Stereotyping Analysis}

Despite the centrality of stereotyping analysis to the Supreme Court's modern sex discrimination jurisprudence, the Court does not look for stereotyping in deciding whether to apply the heightened scrutiny standard of Craig v. Boren. ${ }^{37}$ Instead, the Court looks for a sex-based classification, ${ }^{35}$ it applies heightened scrutiny only if the challenged law divides those affected by the statute into two groups, one composed solely of men and the other solely of women. The Court asks whether a statute rests on stereotypes only after determining that a statute creates a sex-based distinction and only in evaluating whether the state interests are sufficient to justify a sexdiscriminatory law. If either the state interests or the means used to achieve them refiect stereotypical assumptions about women's proper roles, the statute cannot pass constitutional muster.

We can see the structure of the Court's stereotyping analysis most clearly in Hogan. The first inquiry in any sex discrimination case brought under the Equal Protection Clause is whether the challenged policy "discriminates ... on the basis of gender."39 Writing for the Hogan Court, Justice O'Connor compared the position of the plaintiff (in this case a male) with that of a "similarly situated female," created a sex-based classification. The Court proceeded to ask whether the discriminatory policy served "important governmental objectives" whether the discriminatory means employed were "'substantially related to the achievement of those objectives." examined the interests the state actually sought to achieve and questioned whether they rested on stereotypes about women's proper roles. ${ }^{43}$

The Court first looked to see if the goals of the statute rested on normatively offensive assumptions about women's proper roles. As the Court explained, the Craig standard

36. Within this category of differences are those that define what it means to be female and male, such as biological characteristics associated with sexuality and reproduction. See Freedman, supra note 34. at 923 .

37. 429 U.S. 190 (1976).

38. Id. at 197.

39. Mississippi Univ. for Women v. Hogan, 458 U.S. 718. 723 (1982).

40. Id. at 723 n.8.

41. Id. at 724 (quoting Wengler v. Druggists Mut. Ins. Co., 446 U.S. 142, 150 (1980)).

42. Id.

43. Id. at 728-30 (analyzing actual purpose of challenged statute). 
must be applied free of fixed notions concerning the roles and abilities of males and females. Care must be taken in ascertaining whether the statutory objective itself reflects archaic and stereotypic notions. Thus, if the statutory objective is to exclude or "protect" members of one gender because they are presumed to suffer from an inherent handicap or to be innately inferior, the objective itself is illegitimate. ${ }^{44}$

Finding that the actual purpose of the nursing school policy was to maintain nursing as a women's profession, the Court invalidated the policy because this goal rested on a stereotypical vision of women's roles.

Stereotyping analysis also informed the Court's means-ends inquiry. A substantial relationship between the discriminatory classification and the state's goals is necessary "to assure that the validity of a classification is determined through reasoned analysis rather than through the mechanical application of traditional, often inaccurate, assumptions about the proper roles of men and women." At this stage of the analysis, the Court examined the connection between means and ends in an effort to make sure that the means by which the state has tried to advance its legitimate interests do not reflect overbroad generalizations and assumptions about women's roles. Finding that the nursing school permitted men to audit classes, the Court concluded that the school policy did not further legitimate educational goals. ${ }^{46}$ Rather, it perpetuated constitutionally illegitimate notions about women's proper roles.

The Supreme Court's current sex discrimination analysis merely relies on stereotyping as a means of smoking out unconstitutional sex discrimination. A female plaintiff must prove that a statute treats all men differently from all women before the Court will inquire whether the state policy rests on stereotypical notions of women's roles. The comparison principle thus serves as a gatekeeper to the stereotyping analysis. In cases like Hogan, this structure is not problematic. Because the state policy explicitly provided differential treatment for all men and all women, the Court applied heightened scrutiny and invalidated the policy as having rested on the stereotype that nursing is a profession for women only. ${ }^{47}$

\section{B. Stereotyping and Difference}

\section{The Structure of Sex Discrimination Law}

Where there are categorical sex differences between men and women, however, the structure of sex discrimination law breaks down and serves only

44. Id. at $724-25$.

45. Id. at $725-26$.

46. Id. at $730-31$.

47. See Stephanie M. Wildman, The Legitimation of Sex Discrimination: A Critical Response to Supreme Court Jurisprudence, 63 OR. L. REV. 265, 296 (1984). 
to obscure how state laws perpetuate and reinforce stereotypes about the proper roles of women. As Herma Hill Kay has noted, "The existence of physical sexual reproductive differences and the pervasive social system of ascribed sexual characteristics derived from those differences frequently makes crosssex comparisons impossible or inaccurate. ${ }^{n 8}$ The trouble is not that courts are unable to recognize how the law treats men and women differently, but that the comparison principle prevents courts from scrutinizing legislation that regulates women's conduct in areas, such as reproduction, where men and women are biologically different.

Consider Geduldig v. Aiello, ${ }^{49}$ in which the Court upheld the exclusion of pregnancy-related disabilities from a state disability insurance system. Justice Stewart's opinion for the Court found that the pregnancy exclusion was not discriminatory because, under the insurance program, "[t]here is no risk from which men are protected and women are not. Likewise, there is no risk from which women are protected and men are not." ${ }^{30}$ Significantly, the Court justified its refusal to scrutinize a measure whose total impact fell on women by emphasizing the essential physicality of pregnancy:

While it is true that only women can become pregnant, it does not follow that every legislative classification concerning pregnancy is a sex-based classification like those considered in Reed [v.Reed] and Frontiero [ $v$. Richardson]. Normal pregnancy is an objectively identifiable physical condition with unique characteristics. Absent a showing that distinctions involving pregnancy are mere pretexts designed to effect an invidious discrimination against the members of one sex ... . lawmakers are constitutionally free to include or exclude pregnancy from the coverage of legislation such as this on any reasonable basis, just as with respect to any other physical condition. $^{\text {sI }}$

The Geduldig Court analyzed pregnancy-based classifications as if pregnancy were merely a physical condition appearing in only one sex. Under this analysis, the Court stripped the ability to become pregnant of any social meaning, ignoring the ways in which the legal treatment of pregnancy defines the appropriate roles of women and, consequently, dictates women's place in society. The baseline for the comparison is what men have; equal protection doctrine protects women only to the extent that they seek to be treated like

48. Herma Hill Kay, Models of Equaliry, 1985 U. ILL. L. REV. 39. 78-79.

49. 417 U.S. 484 (1974).

50. Id. at 496-97. Focusing on the terms of the program's classification, the Court found that the program "divides potential recipients into two groups-pregnant women and nonpregnant persons. While the first group is exclusively female, the second includes members of both sexes. The fiscal and actuarial benefits of the program thus accrue to members of both sexes." Id. at 496 n.20.

51. Id. at $496 \mathrm{n} .20$. 
men. ${ }^{52}$ Catharine MacKinnon's critique of the comparison principle applies with full force. "Unquestioned is how difference is socially created or defined, who sets the point of reference for sameness, or the comparative empirical approach itself." ${ }^{13}$ Because the Court treated pregnancy solely as a matter of biology, it failed to see how the state transformed a biological difference between men and women into a social disadvantage for pregnant women. Thus, the Court mystified the existence of stereotypical judgments in pregnancybased legislative classifications. ${ }^{54}$

Pregnancy is a uniquely female physical condition. Because the Court's comparison principle mediates the sex discrimination analysis, this is the only important fact. The analysis ends with the recognition of the pregnancy difference between the sexes, and the Court never applies the stereotyping analysis developed in cases like Hogan. Since pregnancy is not something that happens to men, making distinctions based on pregnancy does not constitute sex discrimination and does not violate the Equal Protection Clause.

Similar reasoning about sex discrimination and stereotyping appears in Cohen v. Chesterfield County School Board..$^{55}$ Cohen involved a constitutional challenge to a school board regulation requiring pregnant teachers to go on maternity leave at the end of the fifth month of pregnancy. ${ }^{56}$ In rejecting a pregnant teacher's claim that the forced pregnancy leave policy discriminated against women, the Court of Appeals for the Fourth Circuit, sitting en banc, reasoned that the regulation did not create a sex-based classification because it "does not apply to women in an area in which they may compete with men." ${ }^{\text {"57 }}$ Emphasizing that pregnancy is simply a physical condition, the court explained:

The fact that only women experience pregnancy and motherhood removes all possibility of competition between the sexes in this area. No man-made law or regulation excludes males from those experiences, and no such laws or regulations can relieve females from all of the burdens which naturally accompany the joys and blessings of motherhood. ... The disabilities and preoccupations of maternity are visited but slightly upon the father.... [I]t is she who must

52. See SUNSTEIN, supra note 6, at 284-85; Robin West, Equality Theory, Marital Rape, and the Promise of the Fourteenth Amendment, 42 FLA. L. REV. 45, 58 (1990).

53. MacKinnon, supra note 30 , at 1287.

54. See Sandra Day O'Connor, Portia's Progress, 66 N.Y.U. L. REv. 1546, 1555 (1991); Siegel, supra note 15, at 269-70; cf. Neil Gotanda, A Critique of "Our Constitution is Color-Blind", 44 STAN. L. RBV. 1, 37-52 (1991) (criticizing the Court's use of formal concept of race that sees race as attribute with no social meaning). Following Gotanda, we might call the Court's treatment of pregnancy "formal-pregnancy."

55. 474 F.2d 395 (4th Cir. 1973) (en banc), rev'd on other grounds sub nom. Cleveland Bd. of Educ. v. LaFleur, 414 U.S. 632 (1974).

56. A teacher could not return to work without providing assurances that care of her child would cause little interference with her job. The regulation also required written notice from a doctor that the teacher was physically fit to work full-time. Cohen, 474 F.2d at 396 n.2.

57. Id. at 397. 
shoulder the principal problems of pregnancy, the labors of childbirth and the care and feeding of the child in the early months of its life. ${ }^{58}$

According to the court, invidious sex-based discrimination only occurs "in situations in which the sexes are in actual or potential competition." 99 To use the court's example, because both men and women can serve as administrators for an estate, a statute preferring the appointment of men to women is invidiously discriminatory. ${ }^{60}$ Under the court's definition, the state can only discriminate against women by failing to recognize similarities between men and women.

Underlying the court's opinion is the notion that the "impact of sex differences on people's lives is natural and inevitable, rather than culturally determined." Judge Haynsworth failed to see the pregnancy leave policy as discriminatory because, to him, biology is destiny. Government regulations recognizing the differences that result from women's childbearing capacity cannot be invalidated as discriminatory because they only recognize the clear facts of biology: Women's role is to bear and rear children. Thus, to Judge Haynsworth, the school board's forced leave policy had no social meaning independent of biology. It implied nothing about women's proper roles.

Similar reasoning appears in the Supreme Court's treatment of abortion. Like pregnancy, the decision to obtain an abortion is an act full of social meaning in American society. ${ }^{62}$ Nonetheless, the Cour has often analyzed the act of abortion as a question involving physical facts about pregnant women's bodies rather than social issues about compelled motherhood and women's roles in American society.

For example, in Bray v. Alexandria Women's Health Clinic, ${ }^{63}$ the Court, relying on its equal protection cases, held that the practice of blockading

58. Id at 397-98. The majority added that if the forced pregnancy leave policy were a sex-based classification, sex-specific statutory rape laws, military regulations requiring men to be clean-shaven, and regulations requiring women, but not men, to keep their breasts covered at beaches would also be cxamples of sex-based discrimination. Id. at 397. All of these examples emphasize the differences between men's and women's bodies and suggest that equal protection senutiny should be minimal, if not nonexistent, where bodily differences exist. The Coun did not, however, recognize the socially constructed nature of these differences. See People v. Santorelli, 600 N.E.2d 232, 236-37 (N.Y. 1992) (Titone, J., concurring) (arguing that statute prohibiting public exposure of women's, but not men's, breasts reinforces archaic stereotypes about women's bodies).

59. Cohen, 474 F.2d at 397.

60. Id. (discussing Reed v. Reed, 404 U.S. 71 (1971)). Under this reasoning, the forced leave policy might have been discriminatory in forcing the plaintiff to leave work even when her ability to teach was the same as any male teacher. The coun did not consider this argument.

61. Freedman, supra note 34, at 945.

62. See CARroll Smith-Rosenberg, Disorderly Conduct. Visions of GeNder in Victorlas AMERICA 217 (Oxford Univ. Press 1986) (1985) ("The abortion issue raises concerns about) the acceptability of woman's participation in the economy. and, more broadly. woman's appropriate role within the home and society. It exemplifies political control of the personal and physiological.").

63. 113 S. Ct. 753 (1993). Bray did not involve an interpretation of the Equal Protection Clause; rather, it presented the question of whether aborion clinic blockades were actionable under 42 U.S.C. $\S 1985(3)(1988)$. 
abortion clinics and preventing all women from obtaining medical services did not constitute the "class-based, invidiously discriminatory animus" ${ }^{44}$ necessary to prove a violation of the deprivation clause of $\S 1985(3){ }^{65}$

In a now-familiar move, the Court emphasized physical facts about women's bodies to explain why the blockaders had no discriminatory animus. Justice Scalia's opinion for the Court found that the requisite animus was not present because the blockaders did not have a purpose that "focuse[d] upon women by reason of their sex." separated from the pregnant woman carrying it, the Court found that the purpose of the blockade was not "directed specifically at women as a class," but rather was a neutral attempt to save fetal life. As the Court explained, the clinic blockaders "define their 'rescues' not with reference to women, but as physical intervention 'between abortionists and the innocent victims." 68 Thus, the Court found that there was no discriminatory animus because the antiabortion blockaders sought to save fetuses, not to harm women.

In reversing the affirmance of a preliminary injunction, the Court treated the blockades as benign exercises in saving fetal life that implied nothing about women's social roles in American society. It never once considered whether the blockades reflected and perpetuated stereotypical notions about women's proper roles. As Justice Scalia conceptualized the issue for the majority, the blockaders' great desire to save fetuses meant that women's equality was not at issue. ${ }^{69}$ The Court did not consider whether the blockaders' desire to save fetuses reflected their views about women's roles as mothers or, if not, whether the blockaders were motivated by stereotypes about women's proper roles as well as by their concern for fetuses. To the Court, massive blockades seeking to prevent women from making medical decisions have no social meaning for women's equality. As in Geduldig, it is only an issue of biology.

Under Bray, sex discrimination only arises when a conspiracy "focuses upon women by reason of their sex." ${ }^{\text {"0 }}$ To use Justice Scalia's example, a conspiracy to prevent women from becoming lawyers would meet this requirement because such a conspiracy would attempt to "'sav[e]' women because they are women from a combative, aggressive profession such as the practice of law."71 Where women are the same as men, as in the ability to practice law, Justice Scalia recognizes the sex-based character of the

\footnotetext{
64. 113 S. Ct. at 759 (quoting Griffin v. Breckenridge, 403 U.S. 88, 102 (1971)).

65. Id. at $759-62$.

66. Id. at 759 .

67. Id.

68. Id. at 759-60 (quoting NOW v. Operation Rescue, 726 F. Supp. 1483, 1488 (E.D. Va. 1989) (internal quotation marks omitted)).

69. As Justice Scalia noted, "Whatever one thinks of abortion, it cannot be denied that there are common and respectable reasons for opposing it, other than hatred of or condescension toward (or indeed any view at all concerning) women as a class ...." Id. at 760.

70. $I d$. at 759.

71. 1 d.
} 
discrimination. Yet, where there is some physical difference between the sexes, such as the ability to be pregnant and carry a fetus, conspiracies that target women because of these sex-linked physical characteristics are sex-neutral. The Court in Bray once again maps issues of sameness and difference onto the definition of sex equality: Sex discrimination can only occur when the law fails to recognize similarities between men and women.

\section{Defining Stereotyping}

Distorting its sex discrimination analysis still further, the Supreme Court has also adopted a very narrow definition of stereotyping, defining it out of existence where there are categorical sex differences between men and women. State laws that classify based on the capacity to become pregnant are subject to heightened scrutiny under the Equal Protection Clause because they distinguish, on their face, between all men and all women, thereby creating a sex-based classification. ${ }^{22}$ In such cases, the Court's stereotyping analysis must be applied. Yet, the Supreme Court, while purporting to apply heightened scrutiny, has in fact given little scrutiny to such laws. Instead, the Court has diluted the anti-stereotyping principle underlying the Equal Protection Clause by defining stereotyping as a failure to recognize similarities between men and women. This definition negates the possibility of stereotyping when the state legislates in an area, such as reproductive capacity, where men and women are different.

For example, in Michael M. v. Superior Court, ${ }^{73}$ the Supreme Cour upheld a California statutory rape law that made only men criminally liable for the act of sexual intercourse with a minor under the age of eighteen. Even under the reasoning of Geduldig and its progeny, this was clearly a sex-based classification. If a man and a woman, both under the age of eighteen, have sexual intercourse, only the man is criminally liable. ${ }^{74}$ In upholding the sexbased statutory rape law, then Justice Rehnquist's plurality opinion synthesized the Court's cases dealing with stereotyping and sex discrimination, explaining that these decisions stood for the "principle that a legislature may not 'make overbroad generalizations based on sex which are entirely unrelated to any differences between men and women or which demean the ability or social status of the affected class."'"7s

72. Such classifications are contrasted with the type at issue in Geduldig and Cohen, where the government subjected pregnant women to differential treatment based on their pregnancy

73. 450 U.S. 464 (1981).

74. Id. at 466 (plurality opinion); id. at 476 (Stewar, J., concurring); td. at 488 (Brennan. J., dissenting); see also LAURENCE H. TRIBE, AMERICAN CONSTIUUTONAL LAW $\$ 16-28$, at 1575 (2d ed. 1988).

75. Michael M., 450 U.S. at 469 (quoting Parham v. Hughes, 441 U.S. 347,354 (1979) (plurality opinion)). The Court never considered whether the law demeaned women. Nor has the Court ever applied this highly subjective standard in any other sex discrimination case. 
Stereotyping, in the plurality's view, cannot occur where men and women are not similarly situated. Stereotyping only exists where the state fails to recognize similarities between men and women. This definition of stereotyping adopts the reasoning about biological difference that we saw in Geduldig, Cohen, and Bray: Discrimination against women because of their capacity to become pregnant does not implicate women's equality since such regulation is based on the sexes' different physical states, not on social judgments about women's roles and abilities.

Having found no possibility of stereotyping in cases where there are categorical differences between men and women, the plurality proceeded to build a standard of review based on these differences. Instead of the intermediate standard of review of sex-based classifications established in Craig v. Boren, ${ }^{76}$ Justice Rehnquist applied an analysis that would permit any state legislation that classifies based on sex where the statute "realistically reflects the fact that the sexes are not similarly situated in certain circumstances." W7 With this "similarly situated" analysis, the plurality reintroduced the same formal conception of pregnancy operating in Geduldig, Cohen, and Bray.

Upholding the law as a measure designed to combat teenage pregnancy, the plurality found that, because only women have the capacity to become pregnant, a statute punishing men, but not women, for the crime of statutory rape did not rest on stereotypical reasoning. As Justice Rehnquist explained:

Because virtually all the significant harmful . . . consequences of teenage pregnancy fall on the young female, a legislature acts well within its authority when it elects to punish only the participant who, by nature, suffers few of the consequences of his conduct. ... [T]he risk of pregnancy . . . constitutes a substantial deterrence to young females. No similar natural sanctions deter males. A criminal sanction imposed solely on males thus serves to roughly "equalize" the deterrents on the sexes. ${ }^{78}$

This passage reproduces stereotypical reasoning while denying its presence. If men are not aggressors in sex, why is there any need to provide an additional deterrent for them? According to the plurality's analysis, the statute does not reflect stereotypes; the facts of reproductive biology make men the aggressors. Women, "by nature," have a built-in deterrent to sex; men do not. Under the plurality's analysis, stereotyping cannot occur where men and women are

76. 429 U.S. 190 (1976).

77. Michael M., 450 U.S. at 469; see also Wendy W. Williams, The Equality Crisis: Some Reflections on Culture, Courts, and Feminism, 7 WOMEN's RTS. L. REP. 175, 182 n.50 (1982) (criticizing Justice Rehnquist's analysis in Michael $M$. for failing to apply established intermediate scrutiny test).

78. Michael M., 450 U.S. at 473. 
different. This analysis denies all social meaning attached to women's capacity to become pregnant.

\section{RETHINKING STEREOTYPING AND DIFFERENCE}

The Supreme Court's stereotyping analysis badly needs a change in focus. Strong judicial language condemning stereotypes about women has suggested that the Court, through the prohibition on stereotyping, has cleansed the statute books of laws that perpetuate stereotypic notions about women and men. In creating this image, but not this reality, the Cour has legitimated sex discrimination. To correct these problems, the Court needs a fuller understanding of stereotypes, one that will dissolve the linkages between stereotyping and sameness.

\section{A. The Lessons of History}

Examining the Supreme Court's sex discrimination analysis under the Equal Protection Clause from a historical perspective illustrates the flaws inherent in the modern Court's equal protection analysis. The Court's refusal to examine the way society constructs women's biological differences from men parallels the Supreme Court's sex discrimination jurisprudence of the late nineteenth and early twentieth centuries. In that era, the Court upheld explicitly sex-based restrictions on women's ability to participate in a wide range of activities on the grounds that women's biological differences from men confined them to particular roles. In that era, as today, the Court refused to look at the socially constructed nature of these differences. As a result, states excluded women from civic life in a variety of areas, reasoning that their childbearing capacity required them to be mothers, not civic participants.

In recognizing the authority of states to bar women from becoming lawyers, Justice Bradley's concurrence in Bradivell v. Illinois" exemplifies the late nineteenth-century Supreme Court's view that women's capacity to bear children destined them to lead lives exclusively in the sphere of home and family:

[T]he civil law, as well as nature herself, has always recognized a wide difference in the respective spheres and destinies of man and woman. Man is, or should be, woman's protector and defender. The natural and proper timidity and delicacy which belongs to the female sex evidently unfits it for many of the occupations of civil life. The constitution of the family organization, which is founded in the divine ordinance, as well as in the nature of things, indicates the domestic

79. 83 U.S. (16 Wall.) 130 (1873). 
sphere as that which properly belongs to the domain and functions of womanhood. ...

... The paramount destiny and mission of woman are to fulfil the noble and benign offices of wife and mother. This is the law of the Creator. And the rules of civil society must be adapted to the general constitution of things ... ${ }^{80}$

The Supreme Court also upheld discriminatory labor laws that imposed strict limitations on women's, but not men's, work outside the home. For example, in Muller v. Oregon, ${ }^{81}$ the Supreme Court upheld a law setting the maximum hours a woman could work outside the home. Although a sexneutral maximum-hour law had been invalidated in Lochner v. New York, ${ }^{82}$ the Court upheld the law, finding that a woman's

physical structure and a proper discharge of her maternal functions-having in view not merely her own health, but the wellbeing of the race-justify legislation to protect her from the greed as well as the passion of man. ... The two sexes differ in structure of body, in the functions to be performed by each . . . ${ }^{83}$

The Supreme Court also relied on biological differences between the sexes to justify women's exclusion from civic obligations. The Court upheld the exemption of women from jury duty on the grounds that "woman is still regarded as the center of home and family life." ${ }^{84}$ Similarly, the Court upheld a statute exempting women, along with blind persons, from the payment of a poll tax. Yet, women, unlike the blind, could qualify for this exemption only if they did not register to vote. In Breedlove v. Suttles, the Court upheld this form of state discouragement of women's political participation, finding that the "burdens necessarily borne by [women] for the preservation of the race" made it permissible for the state to discourage them from voting. ${ }^{85}$

80. Id. at $141-42$ (Bradley, J., concurring). Following Bradwell, states barred women from the practico of law and other professions because of the belief that a woman's duty was to bear children. See ALICB KESSLER-HARRIS, OUT TO WORK: A HISTORY OF WAGE-EARNING WOMEN IN THE UNITED STATES 185-86 (1982) (discussing professions that were closed to women around turn of century).

81. 208 U.S. 412 (1908) (upholding Oregon statute limiting working hours for female laundromat employees).

82. 198 U.S. 45 (1905) (striking down statute setting maximum hours for bakery employees).

83. Muller, 208 U.S. at 422; see also Radice v. New York, 264 U.S. 292, 294 (1924) (upholding legislation barring women from night jobs based on need to prevent impairment of women's "peculiar and natural functions"). The protective labor laws upheld in these cases helped to create a sex-segregated labor market, forcing women to take "lower paid, less desirable jobs" or to stay at home. See Law, supra note 30, at 959 n.14; see also Samuel Issacharoff \& Elyse Rosenblum, Women and the Workplace: Accommodating the Demands of Pregnancy, 94 CoLUM. L. REV. 2154, 2173 (1994) (noting that these protective labor laws imposed added costs on employers hiring women workers).

84. Hoyt v. Florida, 368 U.S. 57, 62 (1961); see also J.E.B. v. Alabama ex rel. T.B., 114 S. Ct. 1419 , 1422-23 (1994) (discussing historical justifications for barring women from serving on juries).

85. 302 U.S. 277, 282 (1937); see also Law, supra note 30, at 958 n.13. 
Other statutes of the late nineteenth century that reflected similar notions about women's proper roles never reached the courts. For example, states compelled women to be mothers through legislation criminalizing abortions. The physicians leading the campaign to criminalize abortion voiced the same stereotypical notions that animated the Court in Bradwell, justifying abortion bans on the grounds that "the chief purpose of women was to produce children; anything that interfered with that purpose, or allowed women to 'indulge' themselves in less important activities, threatened . . . the future of society itself. Abortion was a supreme example of such an interference." 86

This history illustrates the importance of looking at the social meanings attached to women's biology. These social meanings connect women's biology to the roles American society has imposed on women. Throughout American history, women's inequality and subordination have rested on assumptions about the limitations and differences posed by women's reproductive capacity. ${ }^{87}$ By constructing women's reproductive biology as a limitation on the roles women may play, American society has endowed the physical facts of reproductive biology with social meaning. ${ }^{88}$

Any understanding of stereotyping must recognize the connection between women's traditional roles and their reproductive capacity. Judgments about women's reproductive differences from men are not simply judgments about physical facts implying nothing about women's social roles. Stereotyping cannot be understood solely as a failure to recognize similarities between men and women. Indeed, the statutory restrictions upheld in Bradwell and other discriminatory decisions were rooted in stereotypical assumptions about women's roles based on their biological differences from men. "Judgments about women's capacity to bear children play a key role in social definitions of gender roles and thus in the social logic of 'discrimination based on gender as such." 90

86. JAMES C. MOHR, ABORTION IN AMERICA: The ORIGINS ANd EVOLUTION OF NATIONAL POLICY. 1800-1900, at 169 (1978); see also Siegel, supra note 15. al 280-323 (analyzing 19th-century ant1-abortion campaigns); Cass R. Sunstein, Neutraliry in Constiturional Law (with Spectal Reference to Pomography. Abortion, and Surrogacy), 92 ColuM. L. REv. 1. 36 \& n.134 (1992) (arguing that history of abortion restrictions is "closely tied up with ... traditional ideas about women's proper role"). Dr. Montrose Pallen illustrated this point very clearly, linking abortion to the eariy women's rights movement. The ideas of the 19th-century feminist movement, he complained, had "the tendency to force wornen into men's places" and was creating "new ideas of women's duties" convincing women that their "ministrations... as .. mother[s] should be abandoned for the stemer rights of voting and law makung." Montrose A. Pallen. Foeticide, or Criminal Abortion, 3 MED. ARCHIVES 193, 205 (1869), quoted in MOHR. supra, at lOS.

87. See Law, supra note 30 , at 957.

88. Cf. Doe v. Maher, 515 A.2d 134, 159 (Conn. Super. CL. 1986) ("'(W)omen's brology and ability to bear children have been used as a basis for discrimination against them. This discnmination has had a devastating effect upon women." (citations omitted)).

89. See California Fed. Sav. \& Loan Ass'n v. Guerra, 479 U.S. 272. 290 (1987) (recognizung that protective labor legislation of early 20 th century reflected "stereotypical notions about pregnancy and the abilities of pregnant workers").

90. Siegel, supra note 15 , at 269. 
The Supreme Court's equal protection jurisprudence has, in fact, recognized the lessons of this history, but only in part. The Court has invalidated legislation based on the stereotype that women are "childrearers," solely for the home and the rearing of the family, and only [men] for the marketplace and the world of ideas"92 - stereotypes rooted in understandings about women's reproductive biology. The Court, however, has not fully rejected the errors of Bradwell and Muller. It has scrutinized legislation to root out these stereotypes only in cases where the state fails to recognize the similarities between men and women, not where there are categorical differences between the sexes. The lessons of this history go deeper than the Court has recognized. The Court must consider how society constructs women's biological differences from men in all cases, not simply in those where men and women are similarly situated.

\section{B. Learning the Lessons}

Despite Geduldig and its progeny, outside the context of the Equal Protection Clause the Supreme Court has recently begun to realize that sex equality is not accomplished simply by recognizing the similarities between men and women, and that state regulation of women's reproductive lives can perpetuate stereotypical notions of women's proper roles. In so doing, the Court has taken a broader view of the wrongs of its earlier sex discrimination jurisprudence, recognizing that Bradwell and Muller erred by failing to recognize the harm of constructing women's childbearing capacity as a duty limiting their freedom to be full and equal citizens in the world of work and ideas.

In Planned Parenthood v. Casey, ${ }^{93}$ the Supreme Court fused equality themes into its privacy jurisprudence. In reaffirming the Constitution's protection of reproductive freedom, the Court recognized that restrictive abortion laws are premised on a narrow vision of women's roles. ${ }^{94}$ As the

91. Califano v. Webster, 430 U.S. 313,317 (1977).

92. Stanton v. Stanton, 421 U.S. 7, 14-15 (1975).

93. 112 S. Ct. 2791 (1992).

94. This was not the first time that the Supreme Court had discussed sex equality in its privacy jurisprudence. Six years earlier, in Thomburgh v. American College of Obstetricians \& Gynecologists, 476 U.S. 747 (1986), the Court recognized that the right of privacy "extends to women as well as men" and that the Constitution protects the right to choose abortion because "[a]ny other result . . . would protect inadequately a central part of the sphere of liberty that our law guarantees equally to all." Id. at 772 . The Court in Thornburgh fused equality and privacy based on an ideal of equal liberty, not on a stereotyping analysis. There are, however, deep connections between the two. The Court's protection of women's and men's equal liberty to make decisions that are "basic to individual dignity and autonomy," $i d$., ensures that the state does not impose its own vision of the proper roles of women and men. Still, these connections between equal liberty and stereotyping analysis went unexplored in Thomburgh. It is only in Casey that the Court focuses on stereotyping and equality in the abortion context. 
joint opinion of Justices O'Connor, Kennedy, and Souter, joined by Justices Blackmun and Stevens, explained, states may not ban abortions

because the liberty of the woman is at stake in a sense unique to the human condition and so unique to the law. The mother who carries a child to full term is subject to anxieties, to physical constraints, to pain that only she must bear. That these sacrifices have from the beginning of the human race been endured by woman with a pride that ennobles her in the eyes of others and gives to the infant a bond of love cannot alone be grounds for the State to insist she make the sacrifice. Her suffering is too intimate and personal for the State to insist, without more, upon its own vision of the woman's role, however dominant that vision has been in the course of our history and culture. The destiny of the woman must be shaped to a large extent on her own conception of her spiritual imperatives and her place in society. ${ }^{95}$

In its analysis of the challenged provisions, the joint opinion pointed to stereotypical reasoning in the husband-notification statute in concluding that the statute imposed an undue burden on a woman's right of reproductive choice. In invalidating the provision, the Court emphasized that the Constitution forbids state legislation that rests on the assumption that the husband is the head and master of the family. "A State may not give to a man the kind of dominion over his wife that parents exercise over their children." 96 By giving husbands a way to compel their wives to bear children for them, the state had sought to embody into law "the common-law status of married women [that is] repugnant to our present understanding of marriage and of the nature of the rights secured by the Constitution." 97

Significantly, the joint opinion rejected the husband-notification statute's underlying assumptions about women's roles, pointing out that such notions about women's roles "precluded [women's] full and independent legal status under the Constitution." 98 The joint opinion linked the statute's assumptions about women's roles to the stereotypical notions about women's role as mother and their place in the home, ratified in cases like Bradivell and Hoyt. ${ }^{99} \mathrm{By}$ granting husbands the power to force their wives to bear children for them, the Pennsylvania law embodied the view that a woman's role was to bear and raise children for her husband, just as the statutes upheld in Bradwell and Hoyt

95. Casey, $112 \mathrm{~S}$. Ct. at 2807. Later in the joint opinion, the three Justices once agann linked restrictive abortion laws to narrow, stereotypical notions of women's proper roles. In its discussion of stare decisis. the joint opinion explicitly recognized the link between women's reproductive freedom and women's equal citizenship: "The ability of women to participate equally in the economic and social life of the Nation has been facilitated by their ability to control their reproductive lives." Id. at 2809.

96. Id. at 2831.

97. Id.

98. Id. at 2830.

99. See id. at $2830-31$. 
rested on the notion that women should be at home, not practicing law or serving on juries. ${ }^{100}$

Yet the Court did not even mention the Equal Protection Clause in its Casey decision. Rather, it incorporated equality analysis into its discussion of the right to privacy, protected by the Due Process Clause of the Fourteenth Amendment. Only Justice Blackmun also located his argument within the Equal Protection Clause of the Fourteenth Amendment. Like the authors of the joint opinion, Justice Blackmun focused on the stereotypical assumptions animating restrictions on abortion and the notions about women's proper roles underlying them. By restricting women's access to abortion, Justice Blackmun wrote, the state

assumes that [women] owe ... [ [a] duty [to bear children] as a matter of course. This assumption-that women can simply be forced to accept the "natural" status and incidents of motherhood appears to rest upon a conception of women's role that has triggered the protection of the Equal Protection Clause. ${ }^{101}$

Similarly, in International Union, UAW v. Johnson Controls, Inc. ${ }^{102}$ the Supreme Court examined the social meanings tied to a woman's ability to become pregnant as it invalidated an employer's fetal-protection policy under Title VII of the Civil Rights Act of 1964. The Court recognized that American society has excluded women from the world of work and ideas based on their capacity to become pregnant. As Justice Blackmun noted, "Concern for a woman's existing or potential offspring historically has been the excuse for denying women equal employment opportunities."103 In finding discriminatory the exclusion of all women of childbearing capacity from leadexposed jobs, the Court pointed out that the employer had stereotyped "all its female employees as potentially pregnant; that choice evinces discrimination on the basis of sex." ${ }^{104}$ The Court refused to perpetuate stereotypical notions about the limitations posed by the capacity to become pregnant, making clear that "[i]t is no more appropriate for the courts than it is for individual employers to decide whether a woman's reproductive role is more important to herself and her family than her economic role."105

In Casey and Johnson Controls, we see a new conception of stereotyping. That conception is simply not compatible with the view of the plurality in Michael $M$. that stereotypes consist of "'overbroad generalizations based on

100. See discussion supra notes 79-80,84 and accompanying text.

101. Casey, 112 S. Ct. at 2847 (Blackmun, J., concurring in part and dissenting in part).

102. 499 U.S. 187 (1991).

103. Id. at 211 (citing Muller v. Oregon, 208 U.S. 412 (1908)).

104. Id. at 199.

105. Id. at 211 . 
sex which are entirely unrelated to any differences between men and women." 106 The fact that men and women are not similarly situated with respect to reproduction is not decisive. Even where there are no similarly situated men to serve as a comparison, the state can perpetuate stereotypical visions of women's proper roles. This understanding of stereotyping is consistent with the definition used in the psychological literature.

In Casey, as in Johnson Controls, the Court gave a serious look to the social meaning of compelled motherhood in determining women's lives as citizens in American society. We see the focus on social meaning in the Casey joint opinion's discussion of the Fourteenth Amendment's prohibition of laws banning abortions. The joint opinion did not look to whether the state failed to recognize the similarities between men and women, but to how "our history and our culture" have shaped our understandings of women's bodies and the jobs women should perform in society. ${ }^{107}$

The Casey joint opinion recognized that abortion bans force women to be mothers, causing them suffering and limiting their choice of social roles. It realized the constitutional harm of this act of state coercion. At the same time, the joint opinion did not make clear whether the constitutional violation is tied to the fact that the abortion decision is "intimate and personal," or whether it rests on a broader understanding of the harms of forcing a woman into a constricted social role, preventing her from realizing her "own conception of her spiritual imperatives and her place in society." 108

Despite the Casey joint opinion's strong statements about women's equality, the joint opinion also gave states leeway in discouraging abortion and encouraging women to bear children. The Court upheld, on the record before it, counseling sessions and twenty-four-hour mandatory delay periods designed to discourage women from choosing abortion. ${ }^{109}$ The Court did not perceive the interest in discouraging abortion as an interest in forcing women to bear children. It did not recognize in such regulations stereotypical assumptions about women's obligations as mothers. Rather, the joint opinion described such measures as benign, legitimate efforts to protect fetal life, efforts that express nothing about women. Here, we see the same lack of understanding we saw in Bray of the connection between the fetus and the pregnant woman. ${ }^{110}$

106. Michael M. v. Superior Cour, 450 U.S. 464,469 (1981) (plurality opinion) (quoung Partam v. Hughes, 441 U.S. 347, 354 (1979) (plurality opinion)).

107. Planned Parenthood v. Casey, 112 S. CL. 2791, 2807 (1992).

108. Id.

109. The Court, however, left open the possibility that future challenges to these types of provisions might succeed if plaintiffs produced evidence showing that the laws imposed an undue burden on the right to choose abortion. See Planned Parenthood v. Casey, 114 S. Ct. 909.911 (Souter. Cireunt Justice 1994) (denying stay of mandate pending petition for writ of certiorari); Fargo Women's Health Org. v. Schafer. 113 S. Ct. 1668, 1669 (1993) (O'Connor, J., concurring in denial of stay): Casey v. Planned Parenthood. 14 F.3d 848, 863 (3d Cir. 1994) (noting that future challenge to Pennsylvania statule upheld in Casey based on different factual record "might yield a different result on its constitutionality").

110. See discussion supra notes $63-71$ and accompanying text. 
Protecting fetuses is a benign act that has nothing to do with women and the functions they play as American citizens. ${ }^{111}$

The Casey joint opinion's failure to reconcile its focus on stereotyping and sex equality with its recognition of an interest in protecting fetal life is a serious flaw in the joint opinion's analysis. By presenting the interest in potential life as an abstract, acontextual interest, the Court distinguished the interest in fetal life from attempts to control women's bodies. Yet, by refusing to examine the specific contexts in which the state seeks to protect potential life and the means it uses to do so, the Court failed to recognize the ways in which the state's interest in fetal life is inextricably linked to the interest in enforcing women's roles as mothers. Careful scrutiny of the contexts in which the state asserts an interest in protecting fetal life and the means it uses to effectuate that interest can reveal stereotypical reasoning about women's role as mother. ${ }^{12}$ The state raises the interest in fetal life primarily in the abortion context, forcing women to bear children and ensuring that they do not violate social understandings of their proper roles. In other contexts, where assumptions about women's proper roles are not central, the state often does not intervene to protect fetal life. This selectivity of regulation powerfully illustrates how the state's interest in fetal life is connected with assumptions about women's duty to bear children. ${ }^{113}$

Once we understand that stereotyping cannot be limited to cases where the state fails to recognize similarities between men and women, it should be apparent that the structure of sex discrimination law has serious flaws. Casey illustrates these flaws. Under current doctrine, a statute premised on the notion that women's biological differences mandate a narrow range of social roles for women will receive almost no scrutiny under the Equal Protection Clause. As a result of the Court's narrow definition of a sex-based classification, the husband-notification provision in Casey, if reviewed on equal protection grounds, would be subject to the lowest level of scrutiny. ${ }^{114}$ Yet, as the Casey joint opinion illustrates, this statute raises serious sex-equality concerns. Despite the significant implications for women's equality raised by the husband-notification provision, current equal protection doctrine would prevent a court from scrutinizing this provision to ensure that the state had offered weighty justifications for its treatment of married women seeking abortions.

111. The undue burden analysis does not really appear to be the basis for the joint opinion's different responses to the husband-notification and waiting period statutes. The evidence before the Court showed that the mandatory delay imposed severe obstacles, and the joint opinion's dismissal of this evidence was quite unconvincing. See Casey, 112 S. Ct. at 2825. Stereotyping analysis, however, does explain the different outcomes in Casey. Because the joint opinion did not find that the waiting period was based on stereotypes, it did not find any undue burden.

112. See Siegel, supra note 15 , at 363-67.

113. Id. at 365-66; see infra notes $145-46$ and accompanying text.

114. See SUNSTEIN, supra note 6, at 284 (noting that restrictive abortion laws do not violate Equal Protection Clause under current doctrine "because only women can become pregnant"). 
The Casey joint opinion sidestepped this problem by relying on the right to privacy. In other equal protection cases, however, where no other source of constitutional protection is available, the limitations of sex discrimination law will perpetuate sex inequality.

If, as the Supreme Court's case law suggests, a central purpose of the Equal Protection Clause is to forbid states from enacting legislation based on stereotypes about women's proper roles, then the doctrinal structure of sex discrimination law under the Equal Protection Clause must change, especially our current understanding of what constitutes a sex-based classification. The Casey Court's focus on stereotyping suggests that stereotyping analysis provides an approach for doctrinal reform. We need to create a doctrinal structure that permits inquiry into stereotyping where there are sex differences between men and women. Sole reliance on the notions of sameness and difference that we see in Geduldig and Cohen must give way to a new definition of sex-based classifications. As the Court of Appeals for the Seventh Circuit explained in construing Title VII of the Civil Rights Act of 1964, "Discrimination is not to be tolerated under the guise of physical properties possessed by one sex."115

In determining whether a statute creates a sex-based classification, courts should consider whether the statute rests on stereotypical notions of women's proper roles. Currently, courts conduct this inquiry in assessing the validity of the state's justifications for sex-based classifications. Absent a broader definition of sex-based classifications, however, constitutional doctrine does not permit courts to scrutinize statutes premised on stereotypical notions about the limitations posed by women's biological differences from men.

If stereotyping were relevant to the finding of a sex-based classification, courts could carefully scrutinize statutes to ensure that they did not rest on stereotypes about women's biological differences. In her brief in Struck $v$. Secretary of Defense, ${ }^{116}$ Ruth Bader Ginsburg argued for this reconceptualization of sex discrimination law. She argued that "[s]ex discrimination exists when all or a defined class of women (or men) are subjected to disadvantaged treatment based on stereotypical assumptions that operate to foreclose opportunity based on individual merit."117 This standard provides an excellent way of escaping the Supreme Court's narrow understanding of what constitutes a sex-based classification. It allows plaintiffs to show that the challenged policy rests on stereotypes of women's or men's roles without the necessity of

115. Sprogis v. United Air Lines, inc., 444 F.2d 1194, 1198 (7th Cir.), cert. dented, 404 U.S. 991 (1971). Indeed, this is the central principle animating Congress' passage of the Pregnancy Discrimination Act of 1978, 42 U.S.C. $\$ 2000 \mathrm{e}(\mathrm{k})$ (1988). For a discussion of this law, see Intemational Union, UAW v. Johnson Controls, Inc., 499 U.S. 187, 198-99, 204-06, 211 (1991).

116. 409 U.S. 1071 (1972). Struck involved a constitutional challenge to Air Foree regulations requiring the discharge of pregnant officers from the Air Force. For a recent discussion of Struck, see Ginsburg, supra note 4, at 1200-02.

117. Brief of Petitioners at 15, Struck, 409 U.S. 1071 (No. 72-178). 
pointing to a similarly situated male (or female) facing different treatment. It also retains the focus on stereotyping that is the central principle of sex discrimination law under the Equal Protection Clause.

Despite the Court's condemnation of stereotyping in its equal protection cases and the precedent for stereotyping analysis in the Casey joint opinion, scholars have not attempted to critique the flaws in current doctrine by constructing a model of equal protection that truly follows the logic of the Court's stereotyping principle. Sylvia Law has come closest to making the stereotyping inquiry a trigger for heightened scrutiny, calling for a standard that "distinguishes between reproductive biological difference and cultural generalizations and that prohibits regulation of reproductive biology whenever it oppresses women or reinforces cultural sex-role stereotypes."118 Professor Law, however, does not examine the centrality of stereotyping analysis to arguments urging courts to scrutinize statutes for stereotypical reasoning in areas of categorical sex differences. In formulating a model of equal protection, she does not try to show what equal protection law would look like if the Court took its stereotyping analysis seriously. Indeed, she provides little discussion of the Supreme Court's decisions invalidating statutes based on stereotypical notions of women's roles.

Rather than working within existing equal protection doctrine, Professor Law bases her analysis on a modified version of Catharine MacKinnon's antisubordination analysis, which demands that courts scrutinize laws that oppress women. ${ }^{119}$ Law's central concern is with the impact of statutes on women. ${ }^{120}$ The Supreme Court, however, has consistently rejected the notion that if a law has an oppressive impact on women, it should be subject to heightened scrutiny. ${ }^{121}$ Rather, the Court's doctrinal analysis, sounding in antidiscrimination norms, has focused on the purpose and structure of challenged legislation, on ensuring that the reasoning of state actors is not motivated by stereotypical judgments about women. ${ }^{122}$ The stereotyping analysis, unlike Law's antisubordination analysis, fits comfortably within this focus on the reasoning of government officials. ${ }^{123}$

At the same time, stereotyping analysis, as Law recognizes, is clearly rooted in antisubordination values. The Supreme Court scrutinizes the use of stereotypes about the proper roles of women and not about other types of

118. Law, supra note 30 , at 1033.

119. Id. at 1005-13.

120. Id. at 1007-08.

121. See Bray v. Alexandria Women's Health Clinic, 113 S. Ct. 753, 760 (1993) (rejecting proposition that "class-based animus can be determined solely by effect"); Personnel Adm'r v. Feeney, 442 U.S. 256. 271-80 (1979) (rejecting constitutional challenge to veterans statute granting preference to class that was over 98\% male); cf. West. supra note 52, at 61 n.66 (noting that most serious problem with antisubordination approaches to Equal Protection Clause is that courts have rejected them).

122. See Siegel, supra note 15 , at 353 .

123. Indeed, Law's focus on the oppressive impact of a statute is in some ways inconsistent with hor use of stereotyping analysis, which is concerned with the reasoning of govemmental decision makers. 
overbroad generalizations precisely because stereotypes about women's proper roles are inextricably linked to the subordination of women. ${ }^{12 s}$ But while the focus on stereotypical judgments about women's and men's proper roles reflects concerns about the subordination of women, equal protection doctrine does not target the subordination of women per se. Instead, equal protection law requires courts to scrutinize the types of judgments made by government decision makers, reflecting the notion that certain types of judgments about women's and men's roles in society "suggest[] the kind of 'class or caste' treatment that the Fourteenth Amendment was designed to abolish."12s

From a strategic standpoint, given the Supreme Court's current unwillingness to focus equal protection analysis on a law's impact on women, urging the Court to follow the logic of its stereotyping analysis seems like a more effective path for doctrinal change than Law's antisubordination approach. Indeed, by illustrating the problems inherent in the Court's current definition of stereotyping, Casey provides support for this approach.

Finally, there is a deep tension between Professor Law's focus on antisubordination and her stereotyping analysis. In applying her antisubordination analysis to restrictions on access to abortion, she treats pregnancy as a mere physical condition, replicating the formal analysis of pregnancy we saw in Geduldig, Cohen, and Bray. She argues that restrictive abortion laws oppress women because forced pregnancy imposes physical intrusions on women's bodies and prevents women from taking part in the world of work and public life. ${ }^{126} \mathrm{Her}$ analysis looks at pregnancy as a physical condition, not as a socially constructed limitation on women's roles. She does not consider restrictive abortion laws to be based on stereotypes of women's roles; she only considers them oppressive to women. Elsewhere, she also seems to be working within a physiological framework, pointing out that stereotyping is not possible where laws "are tied precisely to the biological fact of pregnancy." "27

Rather than work within this physiological conception, equal protection doctrine needs to free itself from the sameness/difference framework that it currently embraces. While Professor Law tries to reject this framework, she incorporates it into parts of her sex equality analysis by replicating Geduldig's vision of pregnancy as a physical condition. By using instead the Court's focus on stereotyping analysis, begun in cases like Hogan and continued in Casey. with its emphasis on the social construction of women's roles, we can develop a model of equal protection analysis free from the focus on sameness and difference.

124. See supra notes $21-28$ and accompanying text.

125. Plylet v. Doe, 457 U.S. 202, 217 n.14 (1982).

126. See Law, supro note 30 , at 1017.

127. Id. at 1031 . 


\section{RETHINKING STEREOTYPING AND DIFFERENCE: SOME APPLICATIONS}

How should courts apply the approach proposed in this Note to the laws excluding pregnancy-related disability benefits upheld in Geduldig, the forced pregnancy leave policy upheld in Cohen, and the abortion restrictions upheld in Casey, such as the twenty-four-hour mandatory delay provision?

First, courts should evaluate the laws to see whether they rest on stereotypical assumptions about women's proper roles. Both the exclusion of pregnancy-related disability benefits at issue in Geduldig and the forced maternity leave policy of Cohen rest, as Reva Siegel has recognized, on the "social judgment that pregnancy is incommensurate with employment, graphically illustrating the use of public power to transform the physiological act of gestation into a gendered condition of economic dependency."128 Rather than regarding women as important members of the workforce, these discriminatory measures depend on the assumption that pregnant women are only marginal members of the workforce and should have men in their lives who can take care of them while they are pregnant. ${ }^{129} \mathrm{Men}$, as in other areas of civic life, are the norm. As Martha Minow has pointed out,

Only from a point of view that regards pregnancy as a strange occurrence, rather than an ongoing bodily potential, would its relationship to female experience be made so tenuous; and only from a vantage point that regards men as the norm would the [policies] seem unproblematic and free from gender discrimination. ${ }^{130}$

In addition, the lower court in Geduldig recognized that the denial of benefits seemed to have roots in another stereotypical judgment: "the belief that all pregnant women are incapable of work for long periods of time." The court focused not on the underlying assumption that women are marginal members of the workforce, but on the state's assumptions that pregnant women's "delicate condition"" and the inability to work that flows from this condition would lead them to submit large claims. ${ }^{132}$ To prevent any

128. Siegel, supra note 15, at 268; see also Olga Popov, Note, Towards a Theory of Undertlass Review, 43 STAN. L. REV. 1095, 1123-24 (1991) ("The denial of benefits is related to the stereotypo of a male norm in the workplace, in that it reflects the notion that professional people do not-or should not-get pregnant.").

129. In a long line of cases, the Supreme Court invalidated statutes based on similar stereotypical notions about women's role in the workforce. See, e.g., Califano v. Westcott, 443 U.S. 76, 89 (1979); Weinberger v. Wiesenfeld, 420 U.S. 636, 643 (1975).

130. Martha Minow, Making All the Difference: InClusion, Exclusion, and AMERican law 57 (1990).

131. Aiello v. Hansen, 359 F. Supp. 792, 799 (N.D. Cal. 1973) (three-judge court), rev'd sub nom. Geduldig v. Aiello, 417 U.S. 484 (1974).

132. Aiello, 359 F. Supp. at 799. 
stereotypical reasoning, the court held, "each pregnant woman [must] be considered individually." 133

Likewise, the mandatory leave policy upheld in Cohen rests on the assumption that all pregnant women are fragile reproductive vessels who cannot work into the third trimester of pregnancy and must rest for long periods of time. In reviewing the court of appeals' ruling in Cohen, the Supreme Court did not resolve the case on equal protection grounds, but rather found that the statute violated due process protections for procreative freedom by creating an irrebuttable presumption of a pregnant woman's inability to work. In effect, the Court recognized that pregnancy had to be treated individually, not in a stereotypical fashion. ${ }^{134}$ Under the Due Process Clause, the Court held, states could not make stereotypical assumptions about pregnant women's ability to work.

Yet, by basing its decision on the Due Process Clause, the Cour left itself open to then Justice Rehnquist's argument that the irrebuttable presumption doctrine was an "attack upon the very notion of lawmaking itself."135 Stereotyping analysis offers a powerful response to Justice Rehnquist's argument: The legislature may not rely on generalizations concerning pregnant women's ability to work because such generalizations reflect stereotypes that have been used to subordinate women. Unlike most legislative generalizations, generalizations concerning the roles and abilities of women receive special scrutiny under the Equal Protection Clause. This line of reasoning does not challenge the general lawmaking power of the state.

At the core of the stereotypical reasoning behind the mandatory matemity leave policy is not only a descriptive claim about pregnant women's contributions to the workforce, but also a normative judgment that women should be at home preparing to become mothers and taking care of their newborn children, instead of participating in the world of work and ideas. Unlike women who become mothers, men who become fathers are not required to stop working to help care for newborn children. The required leave policy thus rests on the assumption that "responsibility for children disable[s] female parents, but not male parents, for other work-not for biological reasons, but because society had ordered things that way."136

In evaluating the denial of pregnancy-related disability benefits and the forced maternity leave policy, courts should apply heightened scrutiny under the Equal Protection Clause. The policies target only women and rest on stereotypical assumptions of women's roles in society, constituting sex-based classifications. Having determined that heightened scrutiny should be applied,

133. Id.

134. Cleveland Bd. of Educ. v. LaFleur, 414 U.S. 632, 644 (1974); O'Connor, supra note 54, at 1554-55.

135. LaFleur, 414 U.S. at 660 (Rehnquist. J., dissenting).

136. See Ginsburg, supra note 4, at 1202. 
courts should use the well-established intermediate scrutiny standard of Craig v. Boren, considering whether the laws "serve important governmental objectives and [are] substantially related to achievement of those objectives."137

The twenty-four-hour waiting period upheld in Casey presents a slightly more difficult case. The waiting period statute in Casey required a woman to wait twenty-four hours between deciding to undergo and undergoing the procedure. This provision required a woman to make two trips to the abortion clinic before obtaining an abortion, first to obtain the state-approved information discouraging abortion and then, at least twenty-four hours later, to obtain the abortion. The mandatory delay provision should receive heightened scrutiny under the Equal Protection Clause because it reflects the assumption that a woman's proper role is to be a mother and that she must be required to rethink any decision to forgo that role. The statute fundamentally perpetuates the stereotypical notion of the indecisiveness of women, questioning a woman's ability to make decisions about the course of her life. ${ }^{138}$

A mandatory delay requirement seems reasonable at first blush in the abortion context because of the serious nature of the abortion decision and, more significant, because of stereotypical assumptions that women choose to obtain abortions carelessly, without thinking through the implications of their decisions. In Doe v. Bolton, ${ }^{139}$ Justice White characterized a woman's decision to terminate her pregnancy as based on "convenience, whim, or caprice." 140 The same distrust of the decision-making capacity of women seeking abortions continues into the present day. Just last year, during the debate over the inclusion of abortion services in the national health care reform package, Representative Richard Armey argued that providing abortion services in the national health care package would " condone the self-indulgent conduct

137. Craig v. Boren, 429 U.S. 190, 197 (1976).

138. See Popov, supra note 128, at 1130 . Throughout history, men have denigrated women's decisionmaking capabilities, labeling them as careless and indecisive. See Brief Amici Curiae of the Committce for Abortion Rights and Against Sterilization Abuse et al. at $37 \mathrm{n} .15$, Simopoulos v. Virginia, 462 U.S. 506 (1983) (Nos. 81-185, 81-746, 81-1172, 81-1255, \& 81-1623) ("Virgil tells us 'A woman is always a ficklo, unstable thing.' Francis I of France explains, 'Woman often changes; foolish the man who trusts her.' The poet, Aaron Hill says, 'First, then, a woman will or won't, depend on it.' Alexander Pope opinioned, "Women's at best a contradiction still."' (citations omitted)).

139. 410 U.S. 179 (1973).

140. Id. at 221 (White, J., dissenting). Indeed, distrust of women seeking abortions is a common theme. Horatio Storer, one of the leaders in the campaign to criminalize abortion in the 19th century, made clear that women could not make decisions for themselves in the area of reproduction:

If each woman were allowed to judge for herself in this matter, her decision upon the abstract would be too sure to be warped by personal considerations, and those of the moment. Women's mind is prone to depression, and, indeed, to temporary actual derangement, under the stimulus of uterine excitation, and this alike at the time of puberty and the final cessation of menses, at the monthly period and at conception, during pregnancy, at labor, and during lactation .... During the state of gestation the woman is therefore liable to thoughts, convictions even, that at other times she would turn from in disgust or dismay ....

HORATIO ROBINSON STORER, WHY NOT? A BOOK FOR EVERY WOMAN 74-75 (Boston, Lee \& Shepard 1866). 
of the body of a woman who has already demonstrated' that she was 'damned careless with it in the first place."'141

In Casey, in line with these stereotypical judgments, the Court upheld Pennsylvania's mandatory delay period as a "reasonable measure to implement the State's interest in protecting the life of the unborn," finding that "important decisions will be more informed and deliberate if they follow some period of reflection."142 Yet, the state requires a woman to rethink her medical choices only when the choice is to have an abortion. If a woman comes to an abortion clinic and tells the clinic staff that she wants to carry her child to term, the state does not force the woman to return home and rethink her decision. Nor, for example, does the state require a person seeking a triple bypass operation, unquestionably an important decision, to wait a fixed time period to think about his or her decision once it has been made. The state does not require an individual to rethink these important decisions because, unlike in the abortion context, it makes no stereotypical judgment about the decision-making capabilities of the concerned individual.

Thus, the waiting period law cannot simply represent a decision to ensure that women make thoughtful decisions concerning important matters. If a mandatory delay period were the norm in medical decision making, it might be possible to see the Pennsylvania law as a reasonable requirement. Because the state asserts an interest in making people rethink important decisions about their lives only in the abortion context, it is highly doubtful that the statute is necessary for informed decision making. ${ }^{143}$ Rather, as Justice Stevens pointed out in his separate opinion in Casey, the mandatory delay provision "rest[s] on outmoded and unacceptable assumptions about the decisionmaking capacity of women." 144

The dissenters in Casey, while partially correct, failed to recognize the incompleteness of this description of the stereotypical reasoning embodied in the Pennsylvania statute. Neither Justice Stevens' nor Justice Blackmun's stereotyping arguments confronted the state interest in protecting fetal life. As a result, their arguments failed to recognize the ways in which the state interest in protecting the fetus by forcing reconsideration of the abortion decision

141. Katharine Q. Seelye, Ascendance of an Improbable Leader-Richard Keuh Amey. N.Y. TMES. Dec. 6, 1994, at B9; see also Anna Quindlen, Not the Facts. Ma'am. N.Y. TIMES. May 18. 1994, at A23 (criticizing Rep. Armey's speech stereotyping women seeking abortions as careless and unthunking).

142. Planned Parenthood v. Casey, 112 S. CL. 2791, 2825 (1992).

143. Cf. City of Ladue v. Gilleo. 114 S. Ct. 2038. 2044 (1994) (recognizang that exemptions from government regulation may "diminish the credibility of the govemment's rationale" for regulating in first place); Hodgson v. Minnesata, 497 U.S. 417, 454-55 (1990) (finding Minnesota's iwo-parent-notufication requirement for abortion unreasonable because few states, including Minnesota, require consent of both parents for medical procedures to protect child's welfare).

144. Casey, 112 S. Ct. at 2841-42 (Stevens, J., concurring in part and dissenung in part); see also id. at 2851 (Blackmun, J., concurring in par and dissenting in par) (citing Justice Stevens' opinion approvingly). 
merged into an attempt to force women to be mothers. ${ }^{145}$ The statute questions women's decision-making power insofar as women seek to free themselves from the vision of women as mothers. If a woman does not want to follow the role society has chosen for her, the state discourages that choice, requiring her to make additional trips to the clinic, forcing her to pay for the extra travel, and exposing her to further loss of confidentiality.

This becomes apparent when one compares the abortion context to other procedures in which a woman's decision will affect the life of another. In other matters of "life" and "death," the state does not second-guess a woman's decision or require her to wait a specified time period before effectuating her decision. For example, a pregnant woman may refuse medical treatment even though the fetus will not survive without such treatment. "At the heart of that situation, as with abortion, is a decision involving the life or death of the fetus. Yet ... [the woman] is considered competent to make one decision [without a mandatory delay], but not the other."146 Unlike the decision to choose abortion, these other decisions about the type of medical care she will use do not implicate the state's vision of her proper social role. Such treatment may have the effect of ending a pregnancy, but it is not the purpose of the treatment to end a pregnancy. In the case of abortion, however, the state requires a woman to rethink her decision because she is violating social understandings of women's proper roles by using a treatment designed to end her pregnancy. Only in this context, where assumptions about women's proper roles are central, does the state allow fetal life to trump the rights of the woman to make decisions about her medical care. Because of this basis in stereotypes about women's proper roles, a court should subject mandatory delay periods to heightened scrutiny.

Within this new framework, we may still conceptualize sex discrimination law in terms of the comparison principle that is central to modern equal protection law. While many scholars have attacked this focus on comparisons as unhelpful in the context of reproductive regulation, ${ }^{147}$ it is not necessary to abandon the notion of comparing the law's treatment of men and women. ${ }^{148} \mathrm{~A}$ comparison principle need not perpetuate sex discrimination. It need not grant women equality only insofar as they are like men. The comparison principle, as applied by the Supreme Court, has these flaws

145. See Siegel, supra note 15 , at $277,357-59$ (describing state's interest in fetal life as an interest in forcing women to bear children).

146. In re T.W., 551 So. 2d 1186, 1199 (Fla. 1989) (Ehrlich, C.J., concurring). Other examples might include how the state treats a parent's decision to authorize removal of a child's life support system. See $i d$. at 1195 (majority opinion) (noting that unwed minor could authorize discontinuance of life support for child in coma, but could not consent to abortion).

147. See, e.g., Law, supra note 30, at 1009; Wildman, supra note 47, at 267.

148. Indeed, as Kay notes, even equal protection analyses that focus on oppression, stigma, and sex stereotyping, rather than on differential treatment, do not "eliminate the need for comparison." Kay, supra note 48 , at 87 . 
because it compares men and women only on the level of physical similarities between the sexes and does not compare how a law affects the ability of women and men to be full citizens in American society.

At times, however, the Supreme Court has understood that courts can structure comparisons in alternative ways, producing a different understanding of equality. For example, in California Federal Savings \& Loan Ass'n $v$. Guerra, ${ }^{149}$ the Court upheld under Title VII a California law requiring employers to provide unpaid pregnancy disability leave to women workers and to reinstate them following the leave. The Court found that Title VII did not preempt the state statute because both sought to guarantee equality. In finding the California law consistent with Title VII's goal of equal employment opportunity, the Court explained that "[b]y 'taking pregnancy into account," California's pregnancy disability-leave statute allows women, as well as men, to have families without losing their jobs."iso

If taking pregnancy into account is necessary to ensure that women, like men, have the opportunity to keep their jobs while also being able to raise their children, then the exclusion of pregnancy-related disability benefits upheld in Geduldig necessarily works an inequality for women. It prevents women from being workers and mothers at the same time, requiring them to leave their jobs and perpetuating the notion that women's role is as mother, not worker. ${ }^{151}$

The Court's comparison does not focus on any physical similarities between the sexes. Rather than asking whether men and women are similar with respect to pregnancy, Justice Marshall's opinion for the Cour "shifted . . . to a broader comparison of men and women in their dual roles as workers and as family members." "IS2 The Court's focus on whether women and men have multiple roles in the areas of home and work allows for a comparison principle that can be used to recognize and prevent the subordination of women based on their differences from men. Justice Marshall made the norm a female one, "us[ing] women's experiences as the benchmark and call[ing] for treating men equally in reference to women, thus reversing the usual practice." 153

Yet, rather than simply using a female baseline for comparing the sexes in all cases, courts should ensure that women, like men, are full and equal citizens in American society, preventing the state from imposing its vision of

149. 479 U.S. 272 (1987).

150. Id. at 289.

151. See TRIBE, supra note 74, \$16-29, at 1584 ("The proper comparison in Geduld g, therefore, was not between pregnant women and all other nonpregnant workers, but between female employees who had engaged in reproductive behavior and male workers who had done likewise. If no man loses his job... as a result of this activity, neither should any woman.").

152. Minow, supra note 130 , at 58 .

153. Id. at 59. 
the proper roles for each sex. ${ }^{154}$ This is the approach Justice Marshall used in Guerra. If we locate the comparison on the level of social roles, we can also deal with the few cases where men are treated unequally based on their physical sex characteristics. ${ }^{155}$ Most important, where women plaintiffs claim that the state is subjecting them to unequal treatment based on their biological differences, we must use a baseline that does not seize on those differences as a reason for rejecting their claim.

\section{CONCLUSION}

Stereotyping analysis presents a powerful way to attack sex discrimination. Given the long history of using stereotypes to confine women to certain places in society, an equal protection doctrine that focuses on stereotyping can be a strong tool for litigants challenging sex discrimination. In several cases, however, the Supreme Court has stripped the stereotyping inquiry of any force, limiting it to cases in which the state fails to recognize similarities between men and women. This approach has legitimated, in ways that have great force in modern America, stereotypical notions about women's reproductive capacity. The challenge is to create a doctrine that grants women equality as women, not solely as they are like men. The Court's decision in Casey provides us with an excellent opportunity to decenter sex discrimination law, challenging the assumptions about sameness and difference that have been central aspects of the Court's understanding of the Equal Protection Clause. Stereotyping analysis, properly understood, provides a way to mount this challenge from within the framework that the Supreme Court has applied since it began to scrutinize sex-based laws.

154. See Kay, supra note 48 , at 87 ("Women and men are alike in many ways, including the largely untested capacity to develop their own potential free of sex stereotypes.").

155. Id. at 85 \& nn. 340-41. Indeed, Kay points out the ways in which states used rape laws to control African-American men. This case, of course, implicates both racial and sex-based stereotypes. For a discussion of the intersection of race and gender, see Kimberle Crenshaw, Demarginalizing the Intersection of Race and Sex: A Black Feminist Critique of Antidiscrimination Doctrine, Feminist Theory and Antiratist Politics, 1989 U. CHI. LEGAL F. 139. 